\title{
The macrobenthic fauna of rocks and boulders in the Lübeck Bay (Western Baltic Sea) investigated from the Underwater Laboratory "Helgoland"
}

\author{
B. GuLLIKSEN \\ Biological Station; Trondheim, Norway
}

\begin{abstract}
KURZFASSUNG: Die Makrobenthosfauna von Felsblödken und Geröll in der Lübecker Bucht (westliche Ostsee) nadh Untersuchungen vom Unterwasserlabor "Helgoland“ aus. Die Makrobenthosfauna an Felsblöcken und Steinen wurde an einer $15 \mathrm{~m}$ tiefen Lokalität der Lübecker Bucht (westliche Ostsee) während eines Forschungsaufenthaltes im Unterwasserlabor (UWL) "Helgoland" (vom 5. 10. bis 19. 10. 1974) durch Freitauchen untersucht. Die Tiere wurden mit einem speziell für den Taucheinsatz konstruierten Saugprobennehmer aufgesammelt. Die Ascidie Dendrodoa grossularia und der Polychaet Polydora ciliata machten zusammen allein $95,6 \%$ aller gesammelten Tierindividuen aus. Die Artenzusammensetzung änderte sich nicht signifikant in Abhängigkeit vom Neigungswinkel des Anwachssubstrats (Geröll- und Felsbrocken), doch wurden Unterschiede in der Besatzdichte für einige Arten festgestellt. Von vier benthischen Arten wurde eine Schwarmbildung beobachtet: Der Polychaet Nereimyra punctata und die Assel Idotea balthica traten am häufgsten in Proben auf, die während des hellen Tages genommen wurden, die Cumacee Diastylis rathkei war häufig in Proben, die zu Anfang der zweiwöchigen Beobachtungszeit, während der höhere Wassertemperaturen vorherrschten, erbeutet wurden. Ahnliche Korrelationen der Aggregationsaktivität konnten bei dem Nudibranchier Facelina drummondi nicht beobachtet werden.
\end{abstract}

\section{INTRODUCTION}

A study of the benthic fauna of a rocky bottom at $15 \mathrm{~m}$ depth in the Lübeck Bay, Baltic Sea (Fig. 1), was carried out from 5 October to 19 October 1974 during a study visit at the Underwater Laboratory (UWL) "Helgoland". The study was concentrated on the composition and density of the fauna in relation to the angle of inclination of the substrate, but a few other observations on the biology of organisms occurring on rocky bottom substrates in the vicinity of the UWL were also made.

UWL "Helgoland" is a German underwater habitat constructed for saturation diving. It has been in operation since 1969. Information on the technical construction of the habitat and of biological investigations which have been made can be found in papers by Fust \& Oser (1970), Haux (1970), Kinne (1970), Jatzke (1970), KrumBEIN (1971), and LUTHER (1973). 


\section{STUDY AREA}

From July to October 1974 the UWL "Helgoland" was situated in Lübeck Bay, $\mathrm{NW}$ of Travemünde, in the Baltic Sea $\left(54^{\circ} 01^{\prime} 04^{\prime \prime} \mathrm{N}, 10^{\circ} 50^{\prime} 04^{\prime \prime} \mathrm{E}\right)$. The available sampling area formed a circle of ca. $100 \mathrm{~m}$ radius around the UWL. Over most of this circumscribed area the water depth was about $15 \mathrm{~m}$. Most of the samples described in this report were derived from a locality covered with rocks and boulders, situated NE of the UWL.

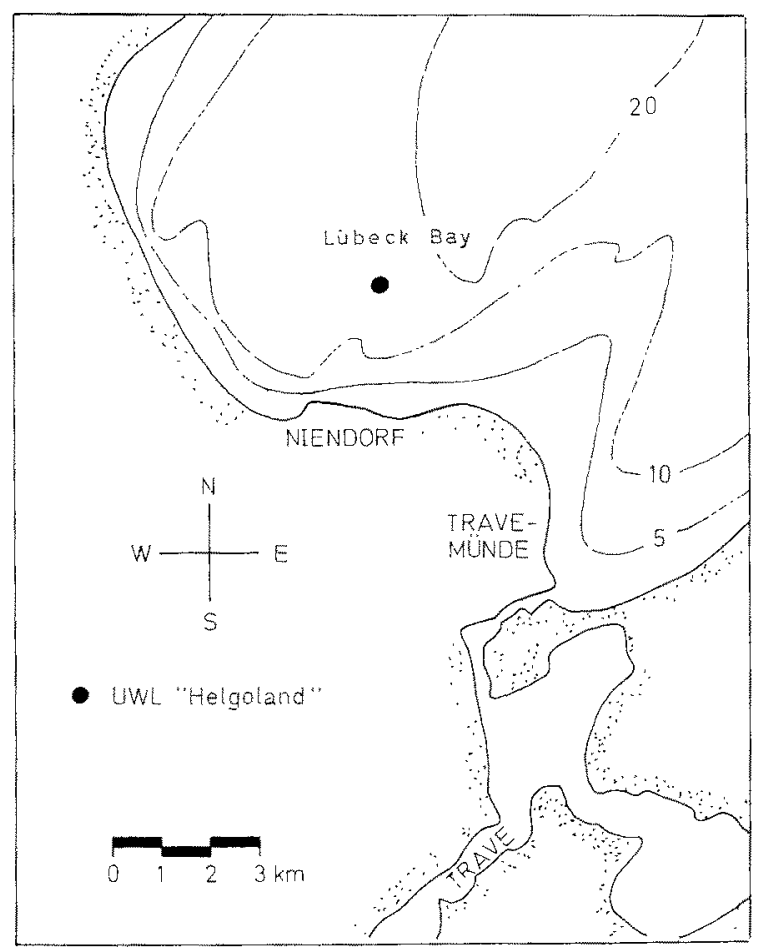

Fig. 1: Map of Lübeck Bay showing the location of the UWL "Helgoland" (in 1974)

The local hydrography showed marked changes between 5-19 October. Near the bottom, the salinity ranged from $16-22 \%$, temperature from $11-14^{\circ} \mathrm{C}$, and the oxygen content from 1.8 to ca. $10 \mathrm{mg} / \mathrm{l}$. During days with strong surface winds, rapid mixing of the water masses close to the bottom was observed. Large surface waves resulted in a $10-20 \mathrm{~cm}$ rise and fall of the water-level at the entrances to the UWL. Water visibility ranged from $2-10 \mathrm{~m}$ during the study period, the mean usually being $5-7 \mathrm{~m}$.

The lower limit of the algal vegetation lies close to $15 \mathrm{~m}$ depth in Lübeck Bay. SegerstrRile (1957) has reported a lower limit of about $20 \mathrm{~m}$ depth for algal vegetation in the Baltic proper. Algal growth on the rocks in the sampling area was therefore 
very much concentrated on the tops of the rocks and boulders, where the light intensity was sufficient for photosynthesis.

\section{MATERIAL AND METHODS}

The sessile and motile organisms on the rocky bottom were sampled with the diver-operated suction sampler described by Gulliksen \& DER̊̊s (1975). This suction sampler is equipped with a sieve of $0.5 \mathrm{~mm}$ mesh, which is the mesh size recommended by MCINTYRe (1964) and Holme \& MCINTYRE (1971) for sampling macrobenthos.

A quantitative sampling of the material from the rocky bottom was achieved by collecting the samples from within a frame which enclosed $1.78 \mathrm{dm}^{2}$ of the bottom. The exact positioning of the frames on the bottom was carried out in the following manner: I swam the last metre towards the rocks with my eyes closed, or simply looking sideways. On touching the rocks with my hand, I placed the frame down, without looking where, and held it firmly on the bottom. The method of "haphazard throwing" or similar methods, could not be used since both vertical and overhanging surfaces were also to be sampled. All bottom material which lay inside the frame was then collected with the suction sampler. A total of 33 samples were taken during the whole survey. The angle of inclination of the substrate, and any other special features, were noted for each sample. Back inside the UWL all animals present were removed from the debris, sorted into their major taxa and thereafter fixed in $80 \%$ alcohol. Specific identifications and counts took place in a laboratory on land.

The frames employed were made of angular aluminum with strips of foam rubber glued to the undersides to prevent any extraneous material from being sucked into the frame. The frame size is relatively small for sampling macrofauna, but this size was found to be the most suitable because of the restricted areas of level surfaces present on the rocks surrounding the UWL. If the rock surface is very uneven, the size of the actual surface sampled will not equal that enclosed by the frame, and extraneous material will also easily be sucked in underneath the edges of the frame if the surface of the bottom is too uneven.

Benthic algae were often found attached to the rocks, especially on the more horizontal surfaces. Animals belonging to the epifauna do also use benthic algae as a substrate. Therefore, when algae are included in the samples the actual surface area available for settlement and, in turn, the area sampled is increased. However, the importance of the increase in surface area involved will be evaluated separately, when discussing the distributions of the respective organisms.

Underwater photography was used to supplement the suction samples collected. The photographs were mostly taken with a Calypso/Nikkor II, equipped with a "Close-up"-attachment and $80 \mathrm{~mm}, 35 \mathrm{~mm}$ or $28 \mathrm{~mm}$ lenses. Information obtained by visual observation is also included.

The abundance of colonies of Porifera and Bryozoa were estimated by a "pointmethod". If only one colony, or fragment of a colony, occurred in a sample, the species was alloted 1 point $(1 \mathrm{p})$; if $2-5$ colonies or fragments occurred, the species received 2 points ( $2 \mathrm{p}$ ); and if the species was very abundant, it was allotted 3 points 
$(3 \mathrm{p})$. The total number of points could then be used to give some idea of the relative numerical importance of each colonial species.

\section{RESULTS}

\section{Faunalcomposition}

Nearly 18000 specimens, comprising at least 43 species, were collected from the rocks in the 33 suction samples, representing a total bottom area of $58.74 \mathrm{dm}^{2}$. The ascidian Dendrodoa grossularia (VAN BENEDEN), together with the polychaete Polydora ciliata (Johnston) constituted $95.6 \%$ of the specimens collected (Table 1).

Dendrodoa grossularia attained its highest densiries on substrates with angle of inclination of $60-89^{\circ}$ (Table 2). The individuals were found attached to both boulders

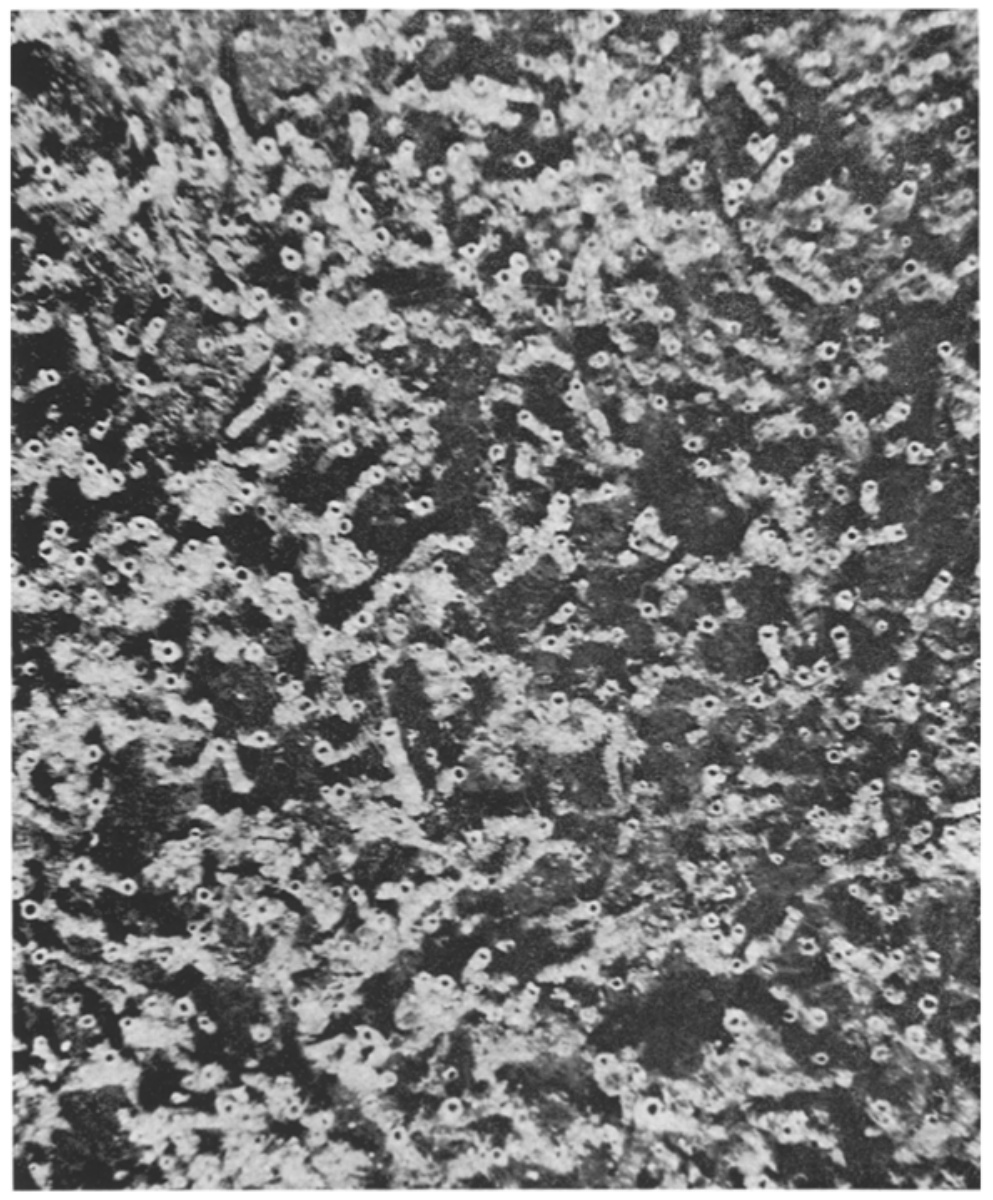

Fig. 2: Rodk covered with specimens of the polychaete Polydora ciliata 
and algae. The range of diameter of the majority of the individuals, from substrates inclined at $0-89^{\circ}$ lay between $1.0-2.0 \mathrm{~mm}$, which indicates that settlement of these individuals occurred during late summer/autumn. The lowest densities were recorded on overhanging substrates. These substrates possessed minimal algal growth and in such sites D. grossularia was found exclusively attached to the rocks. However, these indi-

Table 1

Species counts and species abundance rankings. The abundances of poriferans and bryozoans have been estimated by the "point-method" (see text)

\begin{tabular}{|c|c|c|c|c|c|}
\hline Species & Rank & $\begin{array}{c}\text { Total no. } \\
\text { of } \\
\text { sampled } \\
\text { specimens }\end{array}$ & $\begin{array}{c}\text { Average } \\
\text { no. } / \mathrm{m}^{2}\end{array}$ & $\begin{array}{l}\% \text { of } \\
\text { total }\end{array}$ & $\begin{array}{c}\text { Cumul. } \\
\% \% \text { ge. }\end{array}$ \\
\hline Dendrodoa grossularia (VAN BENEDEN) & 1 & 14023 & 23867 & 78.30 & 78.31 \\
\hline Polydora ciliata (JoHNSTON) & 2 & 3096 & 5269 & 17.29 & 95.60 \\
\hline Nereimyra punctata (MÜLLER) & 3 & 305 & 519 & 1.70 & 97.30 \\
\hline Asterias rubens L. & 4 & 74 & 126 & 0.41 & 97.71 \\
\hline Musculus discors (L.) & 5 & 58 & 99 & 0.32 & 98.03 \\
\hline Neoampbitrite figulus (Dalyell) & 6 & 50 & 85 & 0.27 & 98.30 \\
\hline Idothea baltica (Pallas) & 7 & 47 & 80 & 0.26 & 98.56 \\
\hline Porifera indet. & 8 & $41 \mathrm{p}$ & $70 \mathrm{p}$ & 0.23 & 98.79 \\
\hline Valkeria uva (L.) & 9 & $38 \mathrm{p}$ & $65 \mathrm{p}$ & 0.21 & 99.00 \\
\hline Diastylis rathkei KRÖYER & 10 & 25 & $43^{\mathrm{r}}$ & 0.14 & 99.14 \\
\hline Membranipora indet. & 11 & $20 \mathrm{p}$ & $34 \mathrm{p}$ & 0.11 & 99.25 \\
\hline Facelina drummondi (THомгson) & 11 & $20^{\mathrm{F}}$ & $34^{2}$ & 0.11 & 99.36 \\
\hline Mytilus edulis L. & 13 & 16 & 27 & - & - \\
\hline Harmothoinae indet. & 14 & 13 & 22 & - & - \\
\hline Eucratea loricata (L.) & 15 & $8 \mathrm{p}$ & $14 \mathrm{p}$ & - & - \\
\hline Hydrobia indet. & 16 & 6 & $10^{\mathrm{T}}$ & - & - \\
\hline Terebellides stroemi $\mathrm{M}$. SARS & 16 & 6 & 10 & - & - \\
\hline Nemertini indet. & 18 & 5 & 8 & - & - \\
\hline Hiatella arctica (L.) & 18 & 5 & 8 & - & - \\
\hline Gammarus indet. & 18 & 5 & 8 & - & - \\
\hline Lineus ruber (O. F. MüLLER) & 21 & 4 & 7 & - & - \\
\hline Pboloë minuta (FABRICYUs) & 21 & 4 & 7 & - & - \\
\hline Hydrobia ulvae (PENNANT) & 23 & 3 & 5 & - & - \\
\hline Retusa truncatula (BRUGUIÉRE) & 23 & 3 & 5 & - & - \\
\hline Anaitides maculata (L.) & 23 & 3 & 5 & - & - \\
\hline Scoloplos armiger (MüLLER) & 23 & 3 & 5 & - & - \\
\hline Acarina indet. & 23 & 3 & 5 & - & - \\
\hline Amphipoda indet. & 23 & 3 & 5 & - & - \\
\hline Onoba striata (MONTAGU) & 29 & 2 & 3 & - & - \\
\hline Lepidonotus squamatus (L.) & 29 & 2 & 3 & - & - \\
\hline Polynoidae indet. & 29 & 2 & 3 & - & - \\
\hline Gammarus salinus SPOONER & 29 & 2 & 3 & - & - \\
\hline Thealia felina (L.) & 33 & 1 & 2 & - & - \\
\hline Actinaria juv. & 33 & 1 & 2 & - & - \\
\hline Velutina velutina (MüLLER) & 33 & 1 & 2 & - & - \\
\hline Musculus marmoratus FORBEs & 33 & 1 & 2 & - & - \\
\hline Carditsm juv. & 33 & 1 & 2 & - & - \\
\hline Eumida sanguinea (ORSTED) & 33 & 1 & 2 & - & - \\
\hline Phyllodocinae indet. & 33 & 1 & 2 & - & - \\
\hline Syllidae indet. & 33 & 1 & 2 & - & - \\
\hline Nereidae indet. & 33 & $i$ & 2 & - & - \\
\hline Nymphon indet. & 33 & 1 & 2 & - & - \\
\hline Synascidia indet. & 33 & 1 & 2 & - & - \\
\hline
\end{tabular}


viduals were generally larger than those found on less steeply inclined substrates, averaging $7.0-8.0 \mathrm{~mm}$ in diameter. Many of the larger individuals were found to be semi-decayed, and were greyish-white in colour. Long-term photogrammetric observations in Borgenfjorden, Norway, (Gulliksen in prep.) have shown that D. grossularia here attains its typical morphological characters before the onset of death from longevity. The morphology of the decaying $D$. grossularia near the UWL suggests that death was due to environmental causes, e. g. temporary oxygen deficiency.

\section{Table 2}

Average numbers of individuals per $\mathrm{m}^{2}$ of the most abundant species on substrates at different angles of inclination $\left(0^{\circ}=\right.$ horizontal surface, $90^{\circ}=$ vertical surface, $90^{\circ}-180^{\circ}=$ overhangig surfaces). The abundances of poriferans and bryozoans have been estimated by the "point-method" (see text)

\begin{tabular}{|lcccc|}
\hline \multicolumn{1}{|c}{ Species } & $0-29^{\circ}$ & $30-59^{\circ}$ & $60-89^{\circ}$ & $90-180^{\circ}$ \\
& 10 samples & 12 samples & 4 samples & 7 samples \\
\hline Dendrodoa grossularia & 24943 & 27528 & 53834 & 6534 \\
Polydora ciliata & 7248 & 6044 & 5144 & 321 \\
Nereimyra punctata & 573 & 393 & 337 & 762 \\
Asterias rubens & 236 & 103 & 112 & 16 \\
Musculus discors & 67 & 140 & 126 & 56 \\
Neoampbitrite figuius & 101 & 80 & 84 & 72 \\
Idotea baltica & 84 & 56 & 155 & 72 \\
Porifera sp. indet. & $73 \mathrm{p}$ & $70 \mathrm{p}$ & $98 \mathrm{p}$ & $48 \mathrm{p}$ \\
Valkeria uva & $51 \mathrm{p}$ & $75 \mathrm{p}$ & $84 \mathrm{p}$ & $56 \mathrm{p}$ \\
Diastylis ratblei & 73 & 37 & 42 & 8 \\
Membranipora sp. indet. & 28 & 51 & 14 & 24 \\
Facelina drummondi & 34 & 47 & 28 & 16 \\
Mytilts edulis & 11 & 28 & 28 & 48 \\
Harmothoinae sp. indet. & 45 & 19 & 0 & 8 \\
\hline
\end{tabular}

Polydora ciliata, also, occurred at its lowest densities on overhanging substrates. The densities on substrates inclined at $0-29^{\circ}, 30-59^{\circ}$ and $60-89^{\circ}$ were not significantly different. Polychaete specimens attached to algae have also been included here, and increase in habitat area provided by the algal surfaces may explain the lower densities found on the overhanging substrates, on which few algae were present. The recorded densities of $P$. ciliata may be somewhat underestimated compared to those of $D$. grossularia, because it is more difficult to count a species which has to be dissected out from their tubes than to count an epifaunal ascidian. A photographic survey, 31 pictures each covering an area of $41.9 \mathrm{~cm}^{2}$, confirmed this view. The areas to be photographed were selected in a similar manner to the mode of positioning of the sampling frames. The holes of the tubes (Fig. 2) were counted on the photographs. These indicated an average density of $P$. ciliata of about 33000 individuals $/ \mathrm{m}^{2}$. Many of the tubes were probably empty, but the most correct density estimate for this polychaete probably lies somewhere between 5000 and 33000 individuals $/ \mathrm{m}^{2}$. According to aquanauts who had dived in the same area earlier on in 1974, dense carpets of $P$. ciliata were not present in July and the early part of August. A heavy settlement of P. ciliata had therefore probably taken place during August-September. Settlement during the late summer or autumn fits in well with the life cycle of $P$. ciliata in the Schwentinemin- 
dung, as outlined by ScHürz (1964). This euryhaline polychaete lives for about one year.

The distribution patterns of the three most abundant species, $D$. grossularia, $P$. ciliata and Nereimyra punctata (MÜLLER) were tested using FISHER's "coefficient of dispersion". The coefficient of dispersion is the ratio between the variance and the mean and is given by the equation: $\Sigma(\mathrm{x}-\overline{\mathrm{x}})^{2} / \overline{\mathrm{x}}(\mathrm{n}-\mathrm{L})$. It is possible to use this equation when the average number of individuals per sample $(\bar{x})$ exceeds 5 (ENGEN, pers. comm.). The coefficient of dispersion approaches unity when the individuals are randomly distributed, is less than unity when they are evenly distributed and more than unity when they are aggregated. It is now a widely-used parameter in marine biology (i. e. Holme, 1950; David \& Moore, 1954; Clark \& Milne, 1955; Angel \& Angel, 1967; Strömgren et al., 1973). The coefficients obtained were 858 for D. grossularia, 96 for $P$. ciliata and 9 for $N$. punctata. All these values indicate some degree of aggregated distribution.

Two of the remaining ten most abundant macrobenthic species, the echinoderm Asterias rubens L. and the cumacean Diastylis ratbkei KröYER, seem to have preferences regarding the angle of inclination of the substrate. Both $A$. rubens and $D$. rath$k e i$ showed lower densities on overhanging substrates. Both species are motile. $A$. rubens is a voracious predator, and its distribution is probably governed by the availability of prey. D. rathkei is not a true rocky bottom species, but it swarms occasionally in the water (see next chapter) and when it "accidentally" lands on the rocks it is not surprising that it is found more abundantly on the more horizontal surfaces.

One of the other conspicuous animals, the nudibranch Facelina drummondi (Thompson) was not present during July and August according to the reports of earlier aquanauts. Many of these nudibranchs were spawning during the two weeks I spent in the UWL and their eggstrings were common on the bottom.

Three species which were observed on rocky bottoms when diving were not sampled with the suction pump during the survey. They were the crustacean Balanus crenatus Brugrére, and the two ascidians Ciona intestinalis (L.) and Styela coriacea (ALDER \& HANCOCK), but all were sparsely distributed.

\section{Swarming by benthic animals}

Four of the five most abundant motile benthic animals which were sampled with the suction device were observed swarming throughout the water column. This phenomenon of swarming by benthic invertebrates was also studied by ANGER \& VALENTIN (in prep.), but some observations are included here because of their impor tance for an understanding of the composition of the benthic fauna on the rocky bottom.

Two of the four species, Nereimyra punctata and Idotea baltbica (PALLAs), were most abundant in the samples taken during the middle of the day, when the light intensity was highest (Fig. 3). Neither of these two species seemed to show any special preference regarding to the angle of inclination of the substrate.

The cumacean $D$. ratbkei was common in the samples collected on the first days 
of sampling, while during the last few days it was hardly observed at all up in the water over the bottom (Fig. 3). According to ANGER (pers. comm.), swarming D. rathkei were much more abundant in 1974 during his first study period, 3-17 August, than during his second period, 12-19 October. Swarming behaviour is characteristic of many cumacean species. It has been suggested that swarming may be an adaptation

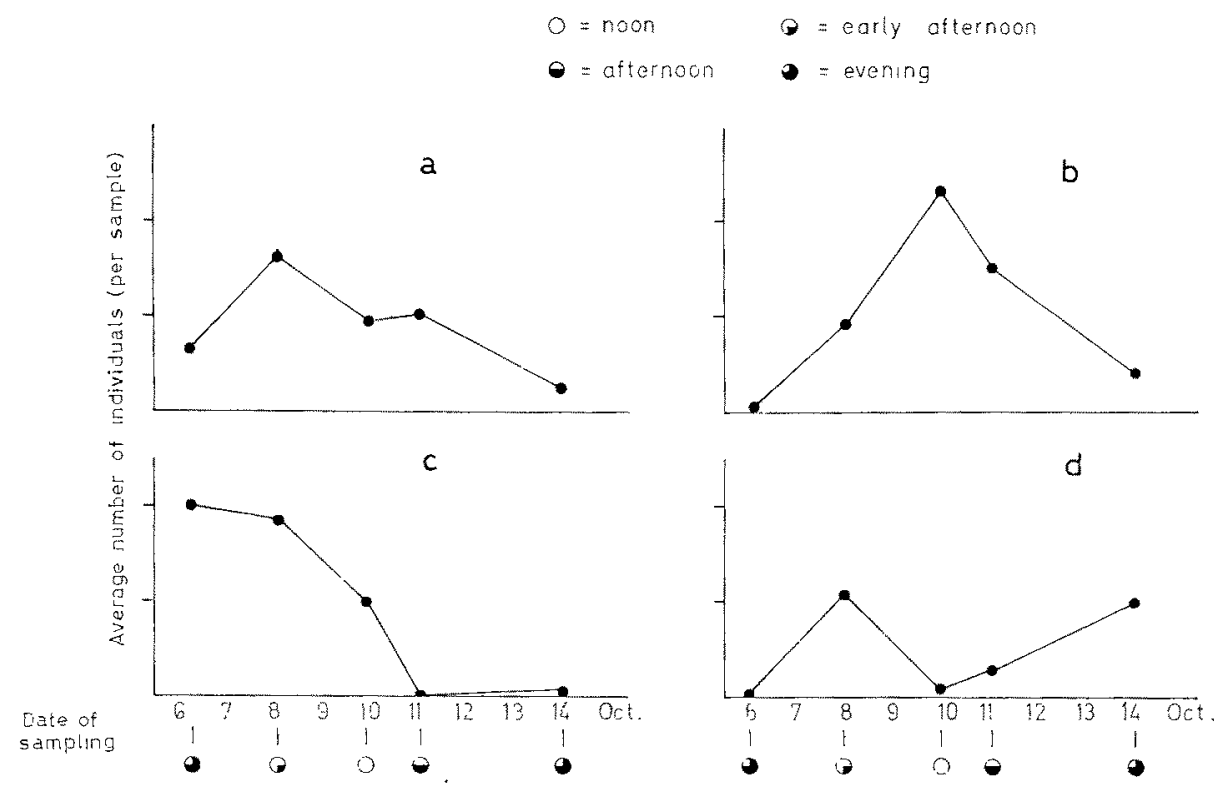

Fig. 3: Average number of individuals per sample $\left(178.0 \mathrm{~cm}^{2}\right)$, on the five separate sampling dates, for (a) Nereimyra punctata, (b) Idotea baltbica, (c) Diastylis ratbkei, and (d) Facelina drummondi

that facilitates mating (BARnes, 1963). ANGER \& VALENTIN closely studied the swarming behaviour of $D$. rathkei in August and found that this cumacean sloughed its exoskeleton whilst hovering in the water. Ecdysis also took place during swarming in October. Swarming of $D$. rathkei may therefore form part of the moulting process of this cumacean.

D. ratbkei is a species which usually lives buried in sand and mud. It occurred in the present samples from hard bottom substrates because the species also chances to land on rocks after swarming. The swarming occurrence of $D$. ratbkei did not seem to show any direct relationship with light conditions, and its sudden disappearance from the samples taken during the last few days of the study period may correspond with a sudden fall in water temperature, from $14^{\circ} \mathrm{C}$ to $11^{\circ} \mathrm{C}$.

! The occurrence of the fourth swarming species found in the samples, F. drummondi, did not seem to be related at all to the times of the day at which the samples were taken (Fig. 4). 


\section{DISCUSSION}

The macrobenthic fauna of the rocks is relatively poor in number of species. This is not exceptional for those areas of the Baltic Sea which have relatively brackish water. The salinity ranged from 16-22\% during the survey period, but it can probably often be lower. In general, the Baltic Sea also possesses a relatively species-poor fauna on hard bottom substrates (cf. THEEDE, 1974).

All the animals found in the samples from the rocky bottom probably do not occur only on rock surfaces or on attached algae. The main habitat of some of the recorded animals may be in or on the sand deposits present between boulders. 15 of the species were also only recorded on rocks only once or twice. Some of these specimens may well have been stray specimens from nearby sandy or muddy habitats. The main impression gained was that the angle of inclination is of no great importance with regard to the species composition of the benthic fauna of rocky bottoms in Lübeck Bay. Differences in the numbers of animals do occur, especially the numbers of $P$. ciliata, but these differences may partly be due to to the increased surface areas provided by the algal vegetation. This lack of difference can probably be explained by the small size of the individual rocks, which implies the presence of a relatively homogenous environment around the boulders. None of the rocks projected more than one metre above the bottom and the most profound differences in numbers found were those related to differences in the distribution of algal vegetation on the rocks.

In the ranking of the animals, the numerical dominance of the species was determined. Functional dominance or importance is in no way implied. This numerical ranking may well change a great deal during the course of the year, as well as from one year to the next. The macrobenthic fauna of the rocks probably does show large annual fluctuations. $P$. ciliata, for instance, was not present earlier on in the summer, and a heavy settlement of $D$. grossularia took place during the late summer or autumn.

When considering the composition of the fauna found on rocky bottoms, the degree of activity of the motile organisms is of great importance, especially if their natural habitat is the sand or mud adjacent to the rocks. The time of the day at which the samples are taken is therefore of great importance if we are to gain a correct impression of the species composition. Sampling times should therefore be equally spread between day and night.

\section{SUMMARY}

1. A diver-operated suction sampler was used to collect the macrobenthic fauna on a rocky bottom in Lïbeck Bay (Western Baltic Sea) from the Underwater Laboratory (UWL) "Helgoland" in October 1974. A comparison of the faunal composition with the angle of inclination of the substrates was the prime goal of the investigation.

2. The ascidian Dendrodoa grossularia and the polychaete Polydora ciliata constituted $95.6 \%$ of the total number of specimens sampled. The lowest densities of both species occurred on overhanging substrates. Both species appared to have a heavy settlement during the late summer or autumn. 
3. In general, the angle of inclination of the substrate bore little relation to the qualitative composition of the fauna on a rocky bottom in Niendorf Bay, but some of the species (Dendrodoa grossularia, Polydora ciliata, Astrias rubens, Diastylis rathkei) were more sparsely distributed on overhanging substrates.

4. The calculated values for FisHeR's "coefficient of dispersion" indicates that all the three most abundant species (Dendrodoa grossularia, Polydora ciliata, Nereimyra punctata) show some degree of aggregated distribution.

5. Four motile invertebrates, Nereimyra punctata, Idotea balthica, Diastylis rathkei and Facelina drummondi were observed swarming in the water. N. punctata and I. baltbica were most abundant in samples taken during the daytime, $D$. ratbkei was most abundant in samples obtained during the early part of the survey when water temperatures were higher, while no relation could be found between the occurrence of $F$. drummondi and the time of day of sampling. For the ultimate picture of the composition of the fauna on rocky bottom substrates, the time of day at which the samples are taken is of importance, due to the varying degree of activity of the motile benthic invertebrates.

Acknowledgements. This study (contribution No. 188 from Biological Station, Trondheim) was made possible by the support, and the excellent service, provided by the "Gesellschaft für Kernenergieverwertung in Schiffbau und Schiffahrt" and the members of the crew of the UWL „Helgoland“. A travel grant was provided by the Norwegian Research Council for Science and the Humanities. I am grateful to Professor Dr. G. Sundnes and Dr. M. Drehr for their continous encouragement, to Cand. real. T. HolTHE for determining the polychaetes and discussions during the preparation of the manuscript and to Mr. K. M. DerÁs for assistance with the laboratory treatment of the sampled material. I also want to thank my fellow aquanauts, Dr. K. Müllzer, Dr. K. Anger, Mr. H. Demiray, and Mr. J. Rediske for all the assistance they gave me during my visit. Mr. P. A. Taldantine has corrected the English text.

\section{LITERATURE CITED}

ANGel, H. H. \& ANGel, M. W., 1967. Distribution pattern analysis in a marine benthic community. Helgoländer wiss. Meeresunters. 15, 445-454.

Barnes, R. D., 1963. Invertebrate Zoology. Saunders, Philadelphia, 632 pp.

Clark, R. B. \& Milne, A., 1955. The sublittoral fauna of two sandy bays on the Isle of Cumbrae, Firth of Clyde. J. mar. biol. Ass. U.K. 34, 161-180.

David, F. N. \& MoORE, P. G., 1954. Notes on contagious distribution in plant populations. Ann. Bot. 18, 47-54.

Fust, H. D. \& Oser, H., 1970. Die technischen und medizinischen Erkenntnisse aus dem Ersteinsatz des „UWL Helgoland". Meerestechnik 1, 17-23.

Gut.liksen, B. \& DerÅs, K. M., 1975. A diver-operated suction sampler for fauna on rocky bottom. Oikos 26, 246-249.

Haux, G., 1970. Das Haus in der Nordsee. Tauchtechnik, Information (Drägerwerk, Lübeck) $1-15$.

Holme, N. A., 1950. Population-dispersion in Tellina tenuis DA CosTA. J. mar. biol. Ass. U.K. $29,267-280$.

- \& MCINTYRE, A. D., 1971. Methods for the study of marine benthos. Blackwell, Oxford, $334 \mathrm{pp}$.

JATZKE, P., 1970. The trichterkreisel, an in situ device for cultivating marine animals in tidal currents. Helgoländer wiss. Meeresunters. 20, 685-690. 
KINNE, O., 1970. Erste Erfahrungen mit dem UWL „Helgoland“. Meerestechnik 1, 1-5.

KRUMBEIN, W. E., 1971. Sediment microbiology and grain-size distribution, as related to tidal movement, during the first mission of the West German Underwater Laboratory „Helgoland". Mar. Biol. 10, 101-112.

LUther, G., 1973. UWL "Helgoland" - an underwater laboratory for rough sea conditions. Helgoländer wiss. Meeresunters. 24, 45-53.

MCINTYRE, A. D., 1964. Meiobenthos of sublittoral muds. J. mar. Biol. Ass. U.K. 44, 665-675.

SchüTz, L., 1964. Die tierische Besiedlung der Hartböden in der Schwentinemündung. Kieler Meeresforsch. 10, 198-217.

SegerstrÅle, S. G., 1957. Baltic Sea. Mem. geol. Soc. Am. 67, 751-800.

Strömgren, T., LANDE, R. \& EngEN, S., 1973. Intertidal distribution of the fauna on muddy beaches in the Borgenfjord area. Sarsia 53, 49-70.

Theede, H., 1974. Die Tierwelt. I. Okologie. In: Meereskunde der Ostsee. Ed. by L. Magaard \& C. Rhernhermer. Springer, Berlin, 171-188.

Author's address: B. GuLIrKsen

Biological Station

N-7001 Trondheim

Norway 